\title{
The relationship of students' prior knowledge and emotional intelligence to mathematical connection ability
}

\author{
Muhammad Daut Siagian 1, a, *, Suwanto ${ }^{2, \mathrm{~b}}$, Rosliana Siregar ${ }^{1, \mathrm{c}}$ \\ ${ }^{1}$ Department of Mathematics Education, Universitas Islam Sumatera Utara \\ Jl. Sisingamangaraja, Teladan - Medan, Sumatera Utara, 20217, Indonesia \\ ${ }^{2}$ Department of Mathematics Education, STKIP Asy-Syafi'iyah Internasional Medan \\ Jl. Karya Tani No.1, Pangkalan Masyhur, Kota Medan, Sumatera Utara, 20146, Indonesia \\ E-mail: ${ }^{a}$ mdsiagian@fkip.uisu.ac.id, ${ }^{\mathrm{b}}$ suwantompd89@gmail.com, ${ }^{\mathrm{c}}$ roslianasrg@ fkip.uisu.ac.id \\ * Corresponding Author
}

\section{ARTICLE INFO}

\section{Article history}

Received: 4 March 2021

Revised: 12 April 2021

Accepted: 22 June 2021

\section{Keywords}

Emotional intelligence; mathematical connection; prior knowledge; mathematics learning

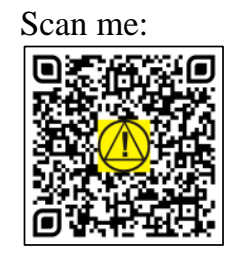

\section{ABSTRACT}

Students should have a good mathematical connection ability to support their learning success. Many factors affect the mathematical connection ability, including prior knowledge and emotional intelligence. This study aimed to describe the simultaneous and partial effect of students' prior knowledge and emotional intelligence on mathematical connection ability. This study involved 34 ninth graders of one of the public junior high schools in Lembang Regency, Indonesia, as the sample. The data was collected using a test consisting of a prior knowledge test and a mathematical connection ability test on the circle topic, and a questionnaire to measure students' emotional intelligence. We analyzed the collected data by descriptive statistics, multiple regression, and partial correlation. The results revealed that the prior knowledge and emotional intelligence together had a significant effect on mathematical connection ability, with a contribution of $23.6 \%$. In addition, there was a significant positive effect between prior knowledge and mathematical connection ability with a contribution of $75.1 \%$ and a significant positive effect between emotional intelligence and mathematical connection ability with a contribution of $12.2 \%$.

This is an open access article under the CC-BY-SA license.

How to Cite: Siagian, M. D., Suwanto, S., \& Siregar, R. (2021). The relationship of students' prior knowledge and emotional intelligence to mathematical connection ability. Jurnal Riset Pendidikan Matematika, 8(1), 61-72. https://doi.org/10.21831/jrpm.v8i1.39182

\section{INTRODUCTION}

Mathematics is one of the compulsory subjects for students in Indonesia, so that mathematical abilities related to the objectives of mathematics learning need to be a concern, as well as mathematical connection ability. Mathematical connection ability is an ability that should be possessed by students (Lubis et al., 2019; NCTM, 1989). Connecting mathematics with other disciplines and mathematics with everyday life is why mathematical connection ability is important. Other reasons are because mathematical connection ability is a medium for long-term memory of mathematical concepts and is a basic ability to master higher abilities (Aliyah et al., 2019; Anita, 2014; Mugita et al., 2019; Ulya \& Irawati, 2016; Sukaesih et al., 2020). Good mathematical connection ability helps students better understand and give meaning to mathematics (Sritresna, 2015).

Mathematical connection ability is an important ability that students should master because it is very useful in understanding mathematical concepts (Sari \& Karyati, 2020). With mathematical connection ability, students can recognize and realize the connection in mathematics and the benefits of mathematics. Hadiat and Karyati (2019) asserted that mathematical connection ability could not be separated from mathematics because every concept, principle, and skill in mathematics is associated with other concepts, principles, and skills. Mathematical connection ability helps students to be able to assess the concepts contained in mathematics as interconnected concepts. 
There are two general types of mathematical connection ability: modeling connections and mathematical connections (see Figure 1). Modeling connections are relationships between problem situations that arise in the real world or other disciplines and their mathematical representations. In contrast, mathematical connections are relationships between two equivalent representations and between the completion process of each representation. Furthermore, NCTM (2000, p. 64) mentioned that there are three aspects that should be mastered by students in mathematical connection ability, namely recognizing and utilizing connections between mathematical ideas, understanding how mathematical ideas are interconnected and constructing one another to produce a coherent whole, and recognizing and applying mathematics in contexts outside of mathematics.

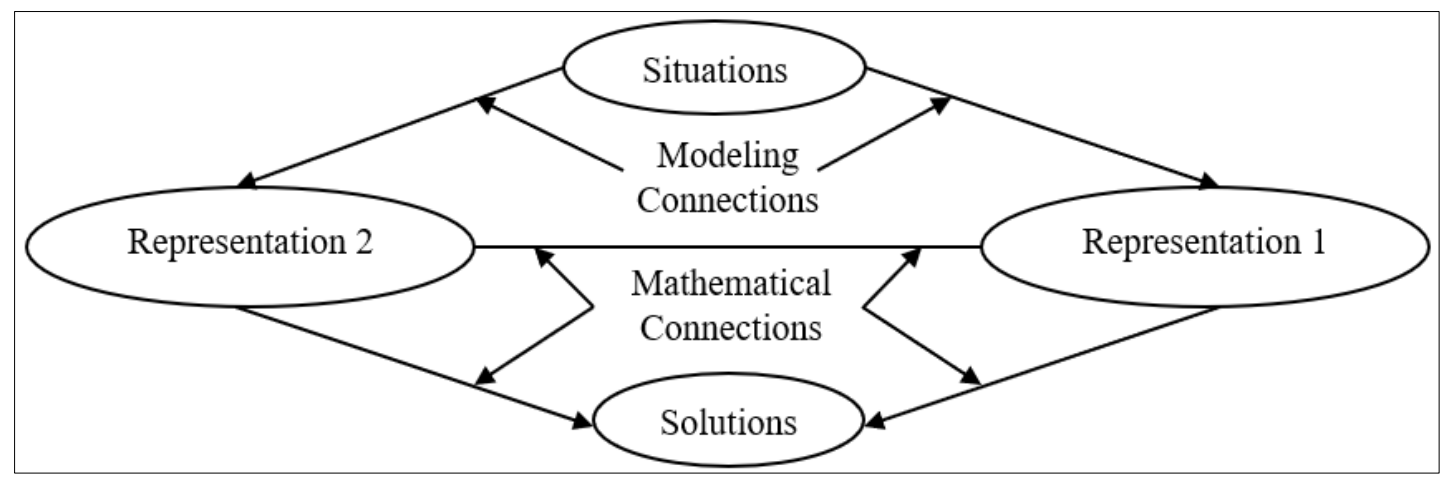

Figure 1. Two general types of mathematical connection ability (Adapted from NCTM, 1989)

Mathematical connection ability can be mastered by understanding the problems associated with the mathematics basic competence or content learned. By making connections, mathematical concepts that have been learned are not left as separate parts but are used as basic knowledge to understand new mathematical concepts. Through a learning process that emphasizes the connection between mathematical ideas, students would learn about mathematics and learn about the usefulness of mathematics (Siagian, 2016). Thus, to improve students' mathematical connection ability, teachers should pay attention to students' prior knowledge (Aliyah et al., 2019).

Prior knowledge has a crucial role in increasing the meaning of learning which impacts facilitating the internal processes in students when learning. Hevriansyah and Megawanti (2016) stated that prior knowledge is essential to facilitate learning activities because it is certain that every basic competence that has been learned will be related to the basic competence that will be learned later. Not only important for students, but this prior knowledge of students is also important for teachers in relation to providing the right portion of difficulties of the learning activities, not too difficult and not too easy. Prior knowledge is a factor supporting the success of learning mathematics (Sukaesih et al., 2020) and is a prerequisite for students' readiness to construct new knowledge (Firmansyah, 2017). Thus, prior knowledge can bridge the information or knowledge that students already have to develop broader and more complex (Cahyani \& Masruroh, 2020).

A student's intelligence could affect the speed in receiving and understanding information and making decisions related to problem-solving (Susanto, 2016). There are several types of intelligence that a person has, such as intellectual intelligence, spiritual intelligence, and emotional intelligence. In this study, emotional intelligence became the main focus concerning students' mathematical connection abilities. Goleman popularized the concept of emotional intelligence in 1995. Goleman (1995) argued that students should learn to recognize and accurately label their emotions at an early age and begin to understand how emotions can affect their behavior. Emotional intelligence is associated with identifying, assessing, and managing emotions in oneself, others, and groups (Chirayath \& Elizabeth, 2013). It is said that emotional intelligence is the ability to reason with emotions and use emotions to facilitate thinking (Musonda, 2017). Emotional intelligence reflects a person's ability to control his emotions in dealing with a problem (Nurmantoro, 2017). Moreover, emotional intelligence is about using emotions intelligently and utilizing the powerful information in emotions to make effective decisions (Matthews et al., 2004).

Concerning learning outcomes or achievement, emotional intelligence could significantly affect learning outcomes (Firmansyah, 2017; Thaib, 2013). Emotional intelligence allows students to cope 


\section{Jurnal Riset Pendidikan Matematika, 8 (1), 2021 - 63}

Muhammad Daut Siagian, Suwanto, Rosliana Siregar

well with the pressures and demands in their learning environment. Nnaji et al. (2020) described emotional intelligence as a spectrum of non-cognitive skills, abilities, and competencies that affect student's ability to cope with environmental demands and pressures. In addition, students who cannot control their mathematics anxiety can negatively affect their mathematical connection abilities (Anita, 2014). Other studies have also consistently shown that mathematics anxiety significantly and negatively correlates with mathematics achievement even after controlling mathematics anxiety (e.g., Ashcraft \& Kirk, 2001). The results of these studies indicate that students who experience mathematics anxiety tend to be unable to control their emotions in the face of pressure and demands in achieving mathematics learning goals.

The results of the study conducted by Nor et al. (2016) showed that mathematical competence should be fostered by stimulating a learning environment that could increase students' emotional stability, especially when they solve mathematics problems. Many students believe that mathematics is a difficult and exhausting subject in their minds, especially mathematics problems that require intensive reading, thinking, analyzing, drawing conclusions, and manipulating symbols and variables. Their emotions when solving mathematics problems should be balanced and well-controlled to maintain their fighting spirit in solving those problems. Musonda (2017) affirmed that students' ability to utilize emotions is important in academic achievement.

Several studies related to prior knowledge, emotional intelligence, and mathematical connection ability have been carried out. Hadiat and Karyati (2019) examined the relationship between mathematical connection ability, curiosity, and self-efficacy and mathematical reasoning ability. The results of their study demonstrated that mathematical connection ability, curiosity, and self-efficacy were simultaneously correlated with students' mathematical reasoning ability. Nnaji et al. (2020) conducted a study to assess the relationship between emotional intelligence and mathematics learning achievement. The results of the study demonstrated a significant positive correlation between emotional intelligence and mathematics learning achievement. Furthermore, the results of the study conducted by Shafiee et al. (2016) showed that there was a significant difference between emotional intelligence and mathematics score. Maree (2013) found that the combination of emotional intelligence and learning orientation dimension could be considered a potential predictor of mathematics learning achievement.

In line with previous studies, this study was also focused on investigating the affective and cognitive domains that affect the attainment of mathematics learning objectives. McLeod (1989) stated that beliefs, attitudes, and emotions are important in studying affective domains in mathematics education. The novelty in this study is that it focuses on analyzing the relationship between cognitive domain (i.e., prior knowledge) and affective domain (i.e., emotional intelligence) on students' mathematical connection ability, which has not been explored so far in previous studies. Accordingly, this study is urgent to provide input for teachers to improve the quality of mathematics learning. In addition, the results of this study are expected to help teachers understand other aspects that could affect students' success in achieving mathematics learning objectives, especially developing mathematical connection ability. Based on the background of the problem and the theoretical study that have been put forward, this study aims to describe the relationship between prior knowledge and mathematical connection ability, the relationship of emotional intelligence to the ability of mathematical connections, and the simultaneous relationship between prior knowledge and emotional intelligence on mathematical connection ability.

\section{METHOD}

The main purpose of this study was to analyze and describe the relationship between students' prior knowledge (with low, medium, and high categories) and emotional intelligence on mathematical connection ability. We did not give any treatment to the sample of this study. This quantitative correlational study employed a survey method to obtain data on students' prior knowledge, emotional intelligence, and mathematical connection ability. A correlational study aims to identify the extent to which variations in a factor are related to variations in one or more other factors based on the correlation coefficient (Kusuma et al., 2016; Narbuko \& Achmadi, 2012). We analyzed the collected data using descriptive statistics and inferential statistics to examine the effect of the independent variables on the dependent variable. In this study, prior knowledge and emotional intelligence are independent variables, while mathematical connection ability is the dependent variable. We obtained 34 ninth graders from a public junior high school, SMP Negeri 5 Lembang, Indonesia, as the sample by employing cluster sampling. 
We administered a test and questionnaire to collect data. Students' prior knowledge data was obtained from prior knowledge test scores. The scores were used for placing students into one of three categories of prior knowledge (i.e., high category when test score $\geq 79.67$, medium category when 32.1 $\leq$ test score $<79.67$, and low category when test score $<32.1$ ). The prior knowledge test comprised 20 multiple-choice items with four options. The items include number, ratio and proportion, algebraic expression and operation, social arithmetic, lines and angles, plane or two-dimensional surface, and the Pythagorean theorem. In addition, emotional intelligence data was obtained through a 5-point Likert scale (i.e., strongly agree, agree, neutral, disagree, and strongly disagree) questionnaire consisting of 15 statements. Table 1 presents the indicators of emotional intelligence and examples of statements of the corresponding indicator.

Table 1. Questionnaire blueprint of emotional intelligence

\begin{tabular}{ll}
\hline Indicators & Example of statements \\
\hline Recognizing emotions & I am aware of my strengths and weaknesses \\
Managing emotions & I am always calm in the face of any situation \\
Motivating oneself & I can obtain good score even though it will be \\
& difficult \\
Recognizing emotions in others (empathy) & $\begin{array}{c}\text { always try to take care of other people's } \\
\text { feelings } \\
\text { I respect other people's opinions even if they } \\
\text { differ from mine }\end{array}$ \\
\hline
\end{tabular}

The mathematical connection ability data was obtained from the results of the mathematical connection ability test. This test consists of three questions with the type of essay on the topic of circles. The mathematical connection test developed should satisfy the following criteria: (1) make students find the connection between processes in a mathematical concept; (2) make students find the connection between one mathematics topic and another mathematics topic; and (3) make students find the connection between mathematics and real-life situations. For example, the following is one of the three mathematical connection ability test items in this study.

A circular garden has a diameter of $42 \mathrm{~m}$. Inside the garden, there is a circular pond with a diameter of $2400 \mathrm{~cm}$. Around the outside of the pond will be planted with grass at the cost of 5000 IDR per $1 \mathrm{~m}^{2}$. Determine the perimeter of the garden and pond in meters and the cost required to plant the grass.

Before collecting data, the instruments (i.e., emotional intelligence questionnaire, prior knowledge test, and mathematical connection ability test) were validated by three lecturers of the Mathematics Education Study Program, State University of Medan, Indonesia. Furthermore, the instruments were piloted on 34 ninth graders SMP Negeri 27 Medan (public junior high school) to examine the readability of the instruments and estimate their reliability. The validation results indicated that the instruments were feasible to use. The reliability coefficient of each instrument was estimated using Cronbach's alpha formula. We obtained the results that the reliability coefficient of the prior knowledge test was 0.72 , the reliability of the emotional intelligence questionnaire was 0.701 , and the reliability coefficient of the mathematical connection ability test was 0.817 . Thus, the reliability coefficient of each instrument demonstrated a high level of reliability, so the instruments were feasible to use.

The instruments were administered to the students directly. Before administering the instrument, we suggested students be ready to work on these instruments. On the first day, students took a prior knowledge test with an allocated time of 60 minutes and filled out an emotional intelligence questionnaire with an allocated time of 30 minutes. A mathematical connection ability test was administered to students on the second day with an allocation of 60 minutes. Furthermore, the data collected were analyzed using descriptive and inferential statistics. The mathematical connection ability data and emotional intelligence data were described by categorization, which refers to Table 2 . 
Table 2. Categories of prior knowledge and emotional intelligence level (Azwar, 2004)

\begin{tabular}{ll}
\hline Score & Category \\
\hline$X \leq M_{i}-1.5\left(S_{i}\right)$ & Very low \\
$M_{i}-1.5\left(S_{i}\right)<X \leq M_{i}-0.5\left(S_{i}\right)$ & Low \\
$M_{i}-0.5\left(S_{i}\right)<X \leq M_{i}+0.5\left(S_{i}\right)$ & Moderate \\
$M_{i}+0.5\left(S_{i}\right)<X \leq M_{i}+1.5\left(S_{i}\right)$ & High \\
$X>M_{i}+1.5\left(S_{i}\right)$ & Very high \\
\hline
\end{tabular}

Inferential statistics was carried out to prove the research hypotheses. Hypothesis testing includes analysis of correlation, regression, and coefficient of determination with the aid of SPSS. A significance level of 5\% (0.05) was used as the criteria for accepting and rejecting the hypothesis. The interpretation of the strength of the relationship between the variables refers to Table 3 .

Table 3. Correlation coefficient and its interpretation (Sugiyono, 2016)

\begin{tabular}{ll}
\hline Correlation coefficient $(r)$ & Interpretation \\
\hline $0.00-0.19$ & Very weak \\
$0.20-0.39$ & Weak \\
$0.40-0.59$ & Moderate \\
$0.60-0.79$ & Strong \\
$0.80-1$ & Very strong \\
\hline
\end{tabular}

\section{RESULTS AND DISCUSSION}

The data obtained in this study are described based on each study variable according to the predetermined category. This section presents and describes the relationship between students' prior knowledge and mathematical connection ability, emotional intelligence and mathematical connection ability, and prior knowledge and emotional intelligence simultaneously to mathematical connection ability.

\section{Description of students' prior knowledge data}

Table 4 presents the results of descriptive analysis of students' prior knowledge data. This data was obtained through a test involving prerequisite material. Students' prior knowledge was categorized into three groups, namely low, medium, and high.

Table 4. Description of students' prior knowledge

\begin{tabular}{lrrrrr}
\hline & $N$ & Min. & Max. & $M$ & $S D$ \\
\hline Low prior knowledge & 7 & 12 & 28 & 22.29 & 3.904 \\
Medium prior knowledge & 20 & 32 & 72 & 55.20 & 9.589 \\
High prior knowledge & 7 & 8 & 96 & 91.43 & 3.599 \\
Prior knowledge (total) & 34 & 8 & 96 & 55.88 & 23.787 \\
\hline
\end{tabular}

Table 4 shows that the mean of students' prior knowledge scores was 55.88, with a standard deviation of 23.787. It implies that the standard deviation is smaller than the mean score in the students' prior knowledge data. Furthermore, this result indicates that the deviation of the data that occurs is low so that the students' prior knowledge scores are evenly distributed. Based on the data in Table 4, it is obtained those seven students have low prior knowledge scores with the mean greater than the standard deviation, 20 students have medium prior knowledge scores with the mean greater than the standard deviation, and seven students have high prior knowledge scores with the mean greater than the standard deviation. These results indicate that the prior knowledge scores are evenly distributed in each prior knowledge category. From the data provided in Table 4, it can be said that students' prior knowledge was quite good, with the percentage of students in the low category was $20.59 \%$, at the medium category was $58.82 \%$, and at the high category was $20.59 \%$. 


\section{Description of students' emotional intelligence data}

Emotional intelligence data was obtained through a questionnaire containing favorable (positive) and unfavorable (negative) statements. The emotional intelligence questionnaire employed a Likert scale. According to Sugiyono (2016), the response to each instrument item that uses a Likert scale has a gradation from very positive to very negative. Based on analysis through descriptive statistics, the mean of students' emotional intelligence scores was $45.63(S D=2.47)$. Based on this result, it can be said that the scores from the students' emotional intelligence questionnaires are evenly distributed because the standard deviation obtained is smaller than the mean score, so that the deviation of the data that occurs is low. The categorization of students' emotional intelligence scores in detail is presented in Table 5. Based on Table 5, it can be concluded that students' emotional intelligence was quite good with a percentage of at least moderate category of $64.71 \%$.

Table 5. Description of students' emotional intelligence

\begin{tabular}{lll}
\hline Skor & Category & $N$ \\
\hline$X \leq 41.93$ & Very low & 7 \\
$41.93<X \leq 44.4$ & Low & 5 \\
$44.4<X \leq 46.87$ & Moderate & 9 \\
$46.87<X \leq 49.34$ & High & 5 \\
$X>49.34$ & Very high & 8 \\
\hline
\end{tabular}

\section{Description of students' mathematical connection data}

Data on students' mathematical connection ability was obtained by giving a test. Based on the test results from 34 students, the minimum score was 29 , the maximum score was 79 , the mean score was 59.32, and the standard deviation was 14.94. The detailed information about students' mathematical connection ability test scores is presented in Table 6.

Table 6. Description of students' mathematical connection ability

\begin{tabular}{llc}
\hline Score & Category & $N$ \\
\hline$X \leq 36,91$ & Very low & 7 \\
$36,91<X \leq 51,85$ & Low & 1 \\
$51,85<X \leq 66,79$ & Moderate & 11 \\
$66,79<X \leq 81,73$ & High & 9 \\
$X>81,73$ & Very high & 6 \\
\hline
\end{tabular}

\section{Relationship between students' prior knowledge and mathematical connection ability}

This study's simple linear regression was used to examine the effect of prior knowledge on mathematical connection ability. The following are the tested hypotheses.

$H_{0}: \beta_{1}=0$ (There is no effect of students' prior knowledge on mathematical connection ability)

$H_{a}: \beta_{1} \neq 0$ (There is the effect of students' prior knowledge on mathematical connection ability)

The regression analysis results demonstrated that students' prior knowledge explained $75.1 \%\left(R^{2}=\right.$ 0.751) of students' mathematical connection ability, while other variables explained the rest. Students' prior knowledge is also a significant predictor of students' mathematical connection ability, $F(1,32)=$ 2.591, $p=0.017$. Students' prior knowledge also contributed significantly to the regression equation model $(B=0.172, p=0.017)$. Moreover, the predictive model of the regression equation is:

Mathematical connection ability score $=49.718+0.172 *$ Prior knowledge score.

The regression equation means that for every increase or decrease of one unit of the prior knowledge variable, it will be followed by an increase or decrease of 0.172 in the mathematical connection ability variable. 


\section{Relationship between students' emotional intelligence and mathematical connection ability}

In order to determine the effect of emotional intelligence on mathematical connection ability, the data analyzed were the emotional intelligence questionnaire and mathematical connection ability test data. The hypotheses tested are:

$$
\begin{aligned}
& H_{0}: \beta_{1}=0 \text { (There is no effect of students' emotional intelligence on mathematical connection } \\
& \text { ability) } \\
& H_{a}: \beta_{1} \neq 0 \text { (There is the effect of students' emotional intelligence on mathematical connection } \\
& \text { ability) }
\end{aligned}
$$

The regression analysis results showed that students' emotional intelligence explained $12.2 \%\left(R^{2}=\right.$ 0.122 ) of students' mathematical connection ability, while other variables explained the rest. Students' emotional intelligence is also a significant predictor of students' mathematical connection ability, $F$ (1, $32)=4.455, p=0.043$. Furthermore, students' emotional intelligence also contributed significantly to the regression equation model $(B=2.115, p=0.043)$. The predictive model of the regression equation is:

$$
\text { Mathematical connection ability score }=-37.2+2.115^{*} \text { Emotional intelligence score } \text {. }
$$

The equation indicates that every increase or decrease of one unit of emotional intelligence variable will be followed by an increase or decrease of 2.115 in the variable of mathematical connection ability.

\section{Relationship of students' prior knowledge and emotional intelligence to mathematical connection ability}

This section examines the relationship between prior knowledge and emotional intelligence simultaneously on mathematical connection ability. In order to obtain an overview of the relationship, hypothesis testing was carried out using a multiple linear regression test with the following hypotheses.

$$
\begin{gathered}
H_{0}: \beta_{12}=0 \text { (There is no effect of students' prior knowledge and emotional intelligence simul- } \\
\quad \text { taneously on mathematical connection ability) } \\
H_{a}: \beta_{12} \neq 0 \text { (There is the effect of students' prior knowledge and emotional intelligence simul- } \\
\text { taneously on mathematical connection ability) }
\end{gathered}
$$

The regression analysis results revealed that students' prior knowledge and emotional intelligence simultaneously were able to explain $23.6 \%\left(R^{2}=0.236\right)$ of students' mathematical connection ability, while other variables explained the rest. The correlation between prior knowledge and emotional intelligence simultaneously on mathematical connection ability was 0.486 , indicating a moderate relationship. Students' prior knowledge and emotional intelligence were also significant predictors of students' mathematical connection ability, $F(2,31)=4.793, p=0.015$. Students' prior knowledge and emotional intelligence also contributed significantly to the regression equation model (Prior knowledge: $B=0.215 ; p=0.039$; Emotional Intelligence: $B=2.465 ; p=0.016$ ). Furthermore, the predictive model of the regression equation is:

$$
\begin{aligned}
\text { Mathematical connection ability score }= & -65.201+0.215^{*} \text { Prior knowledge score }+2.465 * \text { Emotional } \\
& \text { intelligence score }
\end{aligned}
$$

The regression equation implies that the constant is -65.201 , meaning that if the prior knowledge and emotional intelligence are 0 , then the mathematical connection ability is -65.201 . The regression coefficient for the prior knowledge variable is 0.215 . It means that if the other independent variables have a fixed value and the prior knowledge has increased by 1 unit, then the mathematical connection ability will increase by 0.215 . The positive coefficient means that there is a positive relationship between prior knowledge and mathematical connection ability. The higher the prior knowledge, the higher the mathematical connection ability. The regression coefficient of the emotional intelligence variable is 2.465 , meaning that if the other independent variables have a fixed value and emotional intelligence has increased by 1 unit, then the mathematical connection ability will increase by 2.465 . A positive coefficient means that there is a positive relationship between emotional intelligence and mathematical connection ability. The higher the emotional intelligence, the higher the mathematical connection ability. 


\section{Discussion}

This study examines the relationship between students' prior knowledge and emotional intelligence on mathematical connection ability. The results suggest a significant effect of prior knowledge on mathematical connection ability with a contribution of $75.1 \%$. In other words, these results indicate that having a good initial ability will help students understand the next concept. Bringula et al. (2015) revealed that prior knowledge has a consistent, positive, and significant effect on student learning. In addition, teachers need to understand students' prior knowledge as knowledge that will be developed and can develop new knowledge (Lee et al., 2019). In the process, prior knowledge develops depending on student memory (Brucks, 1985), while student memory depends on the psychological condition of students themselves (Hidaayah, 2013). Students will be better prepared to learn when they have good prior knowledge (Astuti, 2015). Thus, this will greatly affect students' mathematics learning outcomes, especially mathematical connection ability, considering that mathematics is hierarchical.

Prior knowledge describes students' readiness to learn or construct knowledge, which is a prerequisite for participating in learning. The readiness of good prior knowledge will help students understand the advanced concepts they will learn. Firmansyah (2017) explained that many students understand what they are learning to depend on prior knowledge, which provides memory for students to find the information they need and when they need it. Several studies also show a relationship between students' prior knowledge and mathematical ability (e.g., Nurmantoro, 2017; Salahuddin, 2018).

In this study, the influence of emotional intelligence on mathematical connection ability is $12.2 \%$. Although not very high, the contribution is significant. The psychological condition of students can change at certain times (Ferrer \& McArdle, 2010); therefore, good emotional control is needed. Students can focus their attention and memory with good emotional control (Gusniwati, 2015). In addition, intellectual intelligence does not function properly without an emotional appreciation of the material being learned (Goleman, 2002). Furthermore, Tjun et al. (2009) explained that someone who has high emotional intelligence would be able to control his emotions to optimize his work to solve a problem well. High emotional intelligence will affect students' mathematics learning outcomes, especially related to the achievement of mathematical connection ability.

According to Ibrahim (2012), emotional intelligence has a significant role in the learning process for students and the quantity and quality of student learning outcomes. In essence, emotional intelligence supports intellectual intelligence to achieve learning success. The study of Hapsyah et al. (2019) demonstrated that emotional intelligence is directly proportional to students' mathematical understanding and problem-solving ability and a decrease in students' emotional intelligence, directly proportional to mathematical understanding and problem-solving ability. Several other studies also show a positive relationship between students' emotional intelligence and mathematical abilities (e.g., Gusniwati, 2015; Merianah, 2019; Setyawan \& Simbolon, 2018; Werdaningsih et al., 2019).

Based on the results of this study, students' prior knowledge and emotional intelligence have a positive effect on mathematical connection abilities. Prior knowledge is the main asset for students to achieve success in learning mathematics, given the hierarchical nature of mathematics (Gusniwati, 2015). Furthermore, emotional intelligence is a person's ability to recognize one's own emotions, manage emotions, motivate oneself in building relationships with others and successfully cope with environmental demands and pressures. Emotional intelligence can determine that students are easy to work with their friends (Gusniwati, 2015). By connecting themselves to others, they will get more information. Emotional intelligence also facilitates learning experiences with what has been remembered (Hoerger et al., 2012). The development of emotional intelligence is important because it can contribute to their cognitive understanding of mathematics as a subject (Alrajhi et al., 2017). Emotionally intelligent students can motivate themselves well and control their emotions so that they can focus their attention on learning mathematics (Purnama, 2016).

By paying attention to students' prior knowledge, teachers can maximize that ability to help students understand the advanced concepts they will learn. Students with good emotional intelligence will be able to control themselves in the learning process to maximize their abilities. Prior knowledge is also influenced by memory, and memory is also influenced by stress levels (Sarafino \& Smith, 2012). The level of stress will impact students' ability to relate what they remember to what they are learning. Thus, students who have high prior knowledge and emotional intelligence will also have high mathematical connection ability. 
Although the findings of this study are in line with expectations, there are still some limitations in practice. First, the subjects in this study were very limited, so that the results in this study could not be generalized widely. Second, the factors that relate to and affect students' mathematical connection ability in this study only consist of two variables, even though many other factors also have a relationship with students' mathematical connection ability, so this study needs to be followed up through further studies. The limitations contained in this study certainly have implications for further studies so that further researchers can consider and control these limitations, such as expanding the study subject so that the study results are more comprehensive and generalizable, expanding the variables related to students' mathematical connection ability, or provide reinforcement or other disclosures such as a rebuttal to the results of this study.

\section{CONCLUSION}

This study concludes that there is a positive relationship between prior knowledge and mathematical connection ability, where students' prior knowledge can explain $75.1 \%$ of mathematical connection ability. In addition, there is a positive relationship between emotional intelligence and mathematical connection ability, where students' emotional intelligence can explain $12.2 \%$ of mathematical connection ability. Furthermore, prior knowledge and emotional intelligence together also have a positive effect on mathematical connection ability. From the two variables analyzed in this study, it can be seen that students' prior knowledge provides a very large contribution to mathematical connection ability. The results show that prior knowledge is an initial asset that students need to have to achieve the goals of learning mathematics. The contribution of prior knowledge and emotional intelligence to mathematical connection ability is only $23.6 \%$, indicating that other variables are related to students' mathematical connection ability. Based on these results, it should be for mathematics education practitioners to develop mathematical abilities by paying attention to factors such as prior knowledge, emotional intelligence, and other factors, hoping that the objectives of learning mathematics can be achieved in the future optimally.

\section{REFERENCES}

Aliyah, I. M., Yuhana, Y., \& Santosa, C. A. H. F. (2019). Kemampuan koneksi matematis siswa ditinjau dari kemampuan awal dan gender [Students' mathematical connection ability in terms of prior knowledge and gender]. Jurnal Didaktik Matematika, 6(2), 161-178. https://doi.org/10.24815/jdm.v6i2.14104

Alrajhi, M., Aldhafri, S., Alkharusi, H., Albusaidi, S., Alkharusi, B., Ambusaidi, A., \& Alhosni, K. (2017). The predictive effects of math teachers' emotional intelligence on their perceived self-efficacy beliefs. Teaching and Teacher Education, 67, 378-388. https://doi.org/10.1016/j.tate.2017.07.003

Anita, I. W. (2014). Pengaruh kecemasan matematika (mathematics anxiety) terhadap kemampuan koneksi matematis siswa SMP [The effect of mathematics anxiety on the mathematical connection ability of junior high school students]. Infinity Journal, 3(1), 125-132. https://doi.org/10.22460/infinity.v3i1.43

Ashcraft, M. H., \& Kirk, E. P. (2001). The relationships among working memory, math anxiety, and performance. Journal of Experimental Psychology: General, 130(2), 224-237. https://doi.org/10.1037/0096-3445.130.2.224

Astuti, S. P. (2015). Pengaruh kemampuan awal dan minat belajar terhadap prestasi belajar fisika [The effect of prior knowledge and interest in learning on physics learning achievement]. Formatif: Jurnal Ilmiah Pendidikan MIPA, 5(1), 68-75. http://dx.doi.org/10.30998/formatif.v5i1.167

Azwar, S. (2004). Metode penelitian [Research methods]. Pustaka Pelajar.

Bringula, R. P., Basa, R. S., Dela Cruz, C., \& Rodrigo, M. M. T. (2015). Effects of prior knowledge in mathematics on learner-interface interactions in a learning-by-teaching intelligent tutoring system. Journal of Educational Computing Research, 54(4), 462-482. http://dx.doi.org/10.1177/0735633115622213

Brucks, M. (1985). The effects of product class knowledge on information search behavior. Journal of Consumer Research, 12(1), 1-16. https://doi.org/10.1086/209031 


\section{Jurnal Riset Pendidikan Matematika, 8 (1), 2021 - 70}

Muhammad Daut Siagian, Suwanto, Rosliana Siregar

Cahyani, K., \& Masruroh, A. (2020). Pengaruh kemampuan awal dan kecerdasan emosional terhadap kemampuan komunikasi matematis [The effect of prior knowledge and emotional intelligence on mathematical communication skills]. Prosiding Seminar Nasional Sains, 462-471.

Chirayath, S., \& Elizabeth, N. G. (2013). Influence of emotional intelligence on learning styles-an exploratory study on management students. Journal of Business Management \& Social Sciences Research, 2(3), 14-23.

Ferrer, E., \& McArdle, J. J. (2010). Longitudinal modeling of developmental changes in psychological research. Current Directions in Psychological Science, 19(3), 149-154.

https://doi.org/10.1177/0963721410370300

Firmansyah, M. A. (2017). Peran kemampuan awal matematika dan belief matematika terhadap hasil belajar [The role of mathematics prior knowledge and mathematical belief on learning outcomes]. Prima: Jurnal Pendidikan Matematika, 1(1), 55-68. https://doi.org/10.31000/prima.v1i1.255

Goleman, D. (1995). Emotional intelligence: Why it can matter more than IQ. Bantam Books.

Goleman, D. (2002). Working with emotional intelligence. Gramedia.

Gusniwati, M. (2015). Pengaruh kecerdasan emosional dan minat belajar terhadap penguasaan konsep matematika siswa SMAN di Kecamatan Kebon Jeruk [The influence of emotional intelligence and interest in learning on the mastery of mathematical concepts of public senior high school students in Kebon Jeruk Sub-district]. Formatif: Jurnal Ilmiah Pendidikan MIPA, 5(1), 26-41. https://doi.org/10.30998/formatif.v5i1.165

Hadiat, H. L., \& Karyati. (2019). Hubungan kemampuan koneksi matematika, rasa ingin tahu dan selfefficacy dengan kemampuan penalaran matematika [Relationship between mathematical connection ability, curiosity, and self-efficacy with mathematical reasoning ability]. Jurnal Riset Pendidikan Matematika, 6(2), 200-210. https://doi.org/10.21831/jrpm.v6i2.26552

Hapsyah, R., Permana, N., \& Zanthy, L. (2019). Pengaruh kecerdasan emosional siswa SMP terhadap kemampuan pemahaman matematik dan pemecahan masalah [The influence of the emotional intelligence of junior high school students on mathematical understanding and problem solving]. Journal on Education, 1(3), 119-127. https://doi.org/10.31004/joe.v1i3.128

Hevriansyah, P., \& Megawanti, P. (2016). Pengaruh kemampuan awal terhadap hasil belajar matematika [The effect of prior knowledge on mathematics learning outcomes]. JKPM (Jurnal Kajian Pendidikan Matematika), 2(1), 37-44. https://doi.org/10.30998/jkpm.v2i1.1893

Hidaayah, N. (2013). Stress pada lansia menjadi faktor penyebab dan akibat terjadinya penyakit [Stress in the elderly is a cause and effect of disease]. Journal of Health Sciences, 6(2), 1-8. https://doi.org/10.33086/jhs.v6i2.29

Hoerger, M., Chapman, B. P., Epstein, R. M., \& Duberstein, P. R. (2012). Emotional intelligence: A theoretical framework for individual differences in affective forecasting. Emotion, 12(4), 716725. https://doi.org/10.1037/a0026724

Ibrahim, I. (2012). Pembelajaran matematika berbasis-masalah yang menghadirkan kecerdasan emosional [Problem-based mathematics learning that promotes emotional intelligence]. Infinity Journal, 1(1), 45-61. http://dx.doi.org/10.22460/infinity.v1i1.p45-61

Kusuma, H., Kristiyanto, A., \& Kiyatno, K. (2016). Hubungan motivasi, tinggi badan dan power otot tungkai terhadap keterampilan bolabasket [The relationship between motivation, height, and leg muscle power on basketball skills]. Media Ilmu Kolahragaan Indonesia, 6(2), 47-53. https://doi.org/10.15294/miki.v6i2.8744

Lee, H. S., Coomes, J., \& Yim, J. (2019). Teachers' conceptions of prior knowledge and the potential of a task in teaching practice. Journal of Mathematics Teacher Education, 22(2), 129-151. https://doi.org/10.1007/s10857-017-9378-y 
Lubis, R., Harahap, T., \& Nasution, P. (2019). Pendekatan open-ended dalam membelajarkan kemampuan koneksi matematis siswa [An open-ended approach to facilitate students' mathematical connection skills]. Mosharafa: Jurnal Pendidikan Matematika, 8(3), 399-410. https://doi.org/10.31980/mosharafa.v8i3.547

Maree, J. G., Fletcher, L., \& Erasmus, P. (2013) The relationship between emotional intelligence, study orientation in mathematics and the mathematics achievement of the middle adolescent, Journal of Psychology in Africa, 23(2), 205-211. http://dx.doi.org/10.1080/14330237.2013.10820616

Matthews, G., Roberts, R. D., \& Zeidner, M. (2004). Seven myths about emotional intelligence. Psychological Inquiry, 15(3), 179-196. https://doi.org/10.1207/s15327965pli1503_01

McLeod, D. B. (1989) Beliefs, attitudes, and emotions: New views of affect in mathematics education. In D. B. McLeod \& V. M. Adams (Eds.) Affect and Mathematical Problem Solving. Springer. https://doi.org/10.1007/978-1-4612-3614-6_17

Merianah, M. (2019). Pengaruh kecerdasan emosional dan adversity quotient terhadap kemampuan pemecahan masalah matematika siswa SDIT Iqra' 1 Kota Bengkulu [The influence of emotional intelligence and adversity quotient on the mathematical problem solving ability of SDIT Iqra' 1 students in Bengkulu City]. Jurnal Pendidikan Matematika Raflesia, 4(1), 29-35. https://doi.org/10.33449/jpmr.v4i1.7526

Mugita, A. R., Nurjamil, D., \& Rustina, R. (2019). Peningkatan kemampuan koneksi dan komunikasi matematis peserta didik melalui model problem based learning dengan strategi REACT [Improving students' mathematical connection and communication skills through a problembased learning model with the REACT strategy]. Journal Authentic Research on Mathematics Education (JARME), 1(1), 46-55. https://doi.org/10.37058/jarme.v1i1.626

Musonda, A. (2017). Algebraic competences and emotional intelligence of first year bachelor of science in mathematics and science education students at the Copperbelt University in Zambia. Tuning Journal for Higher Education, 5(1), 171-195. https://doi.org/10.18543/tjhe-5(1)-2017pp171-195

Narbuko, C., \& Achmadi, A. (2012). Metodologi penelitian [Research methodology]. Bumi Aksara.

NCTM. (1989). Curriculum and evaluation standards for school mathematics. Author.

NCTM. (2000). Principle's standards and for school mathematics. Author.

Nnaji, A. D., Eze, F. B., \& Madu, B. C. (2020). Assessment of emotional intelligence and its relationship with students' achievement in mathematics. International Journal of Mathematics and Statistics Studies, 8(2), 14-25.

Nor, N. A. K. M., Ismail, Z., \& Yusof, Y. M. (2016). The relationship between emotional intelligence and mathematical competency among secondary school students. Journal on Mathematics Education, 7(2), 91-100. http://dx.doi.org/10.22342/jme.7.2.3534.91-100

Nurmantoro, M. A. (2017). Pengaruh kemampuan awal, kecerdasan emosi dan motivasi belajar terhadap kemampuan komunikasi matematis siswa [The influence of prior knowledge, emotional intelligence and learning motivation on students' mathematical communication skills]. Prosiding Diskusi Panel Pendidikan "Menjadi Guru Pembelajar”, 1-11.

Purnama, I. M. (2016). Pengaruh kecerdasan emosional dan minat belajar terhadap prestasi belajar matematika di SMAN Jakarta Selatan [The influence of emotional intelligence and interest in learning on mathematics learning achievement at SMAN Jakarta Selatan]. Formatif: Jurnal Ilmiah Pendidikan MIPA, 6(3), 233-245. http://dx.doi.org/10.30998/formatif.v6i3.995

Salahuddin, I. (2018). Pengaruh kemampuan awal, kepercayaan diri, motivasi belajar terhadap kemampuan komunikasi matematis siswa SMP [The effect of prior knowledge, self-confidence, learning motivation on the mathematical communication skills of junior high school students]. Proximal: Jurnal Penelitian Matematika dan Pendidikan Matematika, 1(2), 144-155.

Sarafino, E. P., \& Smith, T. W. (2012). Health psychology: Biopsychosocial interactions (7th ed.). John Wiley \& Sons. 
Sari, E. P, \& Karyati. (2020). Keefektifan model pembelajaran CORE ditinjau dari kemampuan koneksi matematis, representasi matematis, dan kepercayaan diri siswa [The effectiveness of the CORE learning model in terms of students' mathematical connection ability, mathematical representation, and self-confidence]. Jurnal Riset Pendidikan Matematika, 7(2), 227-240. https://doi.org/10.21831/jrpm.v7i2.35487

Setyawan, A. G., \& Simbolon, D. (2018). Pengaruh kecerdasan emosional terhadap hasil belajar matematika siswa SMK Kansai Pekanbaru [The influence of emotional intelligence on mathematics learning outcomes for Kansai Vocational High School Pekanbaru students]. JPPM (Jurnal Penelitian dan Pembelajaran Matematika), 11(1), 11-18. http://dx.doi.org/10.30870/jppm.v11i1.2980

Shafiee, M., Majdi, H., Khoshkhou, M., \& Rajabi, F. (2016). The processing of relationship between emotional intelligence and mathematics scores. International Journal of Innovation and Research in Educational Sciences, 3(1), 36-39.

Siagian, M. D. (2016). Kemampuan koneksi matematik dalam pembelajaran matematika [Mathematical connection ability in mathematics learning]. MES: Journal of Matematics Education and Science, 2(1), 58-67. https://doi.org/10.30743/mes.v2i1.117

Sritresna, T. (2015). Meningkatkan kemampuan koneksi matematis siswa melalui model pembelajaran cooperative-meaningful instructional design (C-MID) [Improve students' mathematical connection skills through cooperative-meaningful instructional design learning models]. Mosharafa: Jurnal Pendidikan Matematika, 4(1), 38-47.

https://journal.institutpendidikan.ac.id/index.php/mosharafa/article/view/mv4n1_5

Sugiyono. (2016). Metode penelitian kuantitatif, kualitatif dan $R \& D$ [Quantitative, qualitative and R\&D research methods]. Alfabet.

Sukaesih, E., Nindiasari, H., \& Fatah, A. (2020). Pengaruh model connecting, organizing, refleting, extending (core) terhadap kemampuan koneksi ditinjau dari kemampuan awal matematis [The effect of connecting, organizing, reflecting, extending (CORE) models on connection ability in terms of mathematical prior knowledge]. Tirtamath: Jurnal Penelitian dan Pengajaran Matematika, 2(1), 86-100. http://dx.doi.org/10.48181/tirtamath.v2i1.8734

Susanto, A. (2016). Teori belajar dan pembelajaran di sekolah dasar [Learning theory in elementary school]. Prenadamedia Group.

Thaib, E. N. (2013). Hubungan antara prestasi belajar dengan kecerdasan emosional [The relationship between learning achievement and emotional intelligence]. Jurnal Ilmiah Didaktika, 13(2), 384399. https://doi.org/10.22373/jid.v13i2.485

Tjun, L., Setiawan, S., \& Setiana, S. (2009). Pengaruh kecerdasan emosional terhadap pemahaman akuntansi dilihat dari perspektif gender [The influence of emotional intelligence on accounting understanding from a gender perspective]. Jurnal Akuntansi, 1(2), 101-118. https://doi.org/10.28932/jam.v1i2.374

Ulya, I. F., \& Irawati, R. (2016). Peningkatan kemampuan koneksi matematis dan motivasi belajar siswa menggunakan pendekatan kontekstual [Improving students' mathematical connection skills and learning motivation using a contextual approach]. Jurnal Pena Ilmiah, 1(1), 121-130. https://doi.org/10.23819/pi.v1i1.2940

Werdaningsih, R., Sari, Y. Y., \& Azhar, E. (2019). Pengaruh pembelajaran gema dan kecerdasan emosional terhadap kemampuan pemecahan masalah matematis siswa SD [The effect of echo learning and emotional intelligence on the mathematical problem solving ability of elementary school students]. Spektrum Penelitian Pendidikan Dasar, 1(1), 72-79. https://doi.org/10.22236/injope.v1i1.3845 